\title{
Ultrastructural Alterations Induced by Chromium in Polygonum ferrugineum
}

\author{
P.A.Mangabeira, Alex-Alan F. de Almeida, D.C. Silva, A. H. Oliveira, Valéria F. Fernandes, A.J.dos
} Santos Júnior, P. Galle

Centro de Microscopia Eletrônica, Departamento de Ciências Biológicas, Universidade Estadual de Santa Cruz, Rodovia Ilhéus-Itabuna km 16, Ilhéus, Bahia 45662-900, Brazil

It has been demonstrated that aquatic macrophytes have the potential to remove pollutants and can be used as biomarkers for the occurrence of heavy metals in aquatic environments [1]. Metal accumulation in macrophytes is frequently accompanied by cell modifications that may contribute to their metal tolerance [2]. Investigations involving high resolution ion microscopy are scarce in biology [3,4,5], although the technique can be used together with transmission electron microscopy (TEM) for the precise detection of heavy metals in plant tissues and cells. Thus, the location of the metal in the sample can be determined by comparison of ion secondary image (ISI) generated by secondary ion mass spectrometry (SIMS) with the image of the element under investigation. The aim of the present study was to employ TEM and SIMS in order to identify the sites of accumulation of $\mathrm{Cr}$ in Polygonum ferrugineum grown in $\mathrm{CrCl} 3.6 \mathrm{H} 2 \mathrm{O}$ (25 or $50 \mathrm{mg} \mathrm{L}-1)$ and incubated under constant aeration for two weeks.

Modifications in cell ultrastructure detected by TEM analyses of leaves, stems and roots of $P$. ferrugineum that had been incubated in $50 \mathrm{mg} \mathrm{L}-1$ of $\mathrm{Cr}$ are shown in Fig. 1. SIMS analysis are presented in Fig. 2 note were found deposits in cell walls and precipitates of $\mathrm{Cr}$ in root cells. Fig 2 shows the detailed results of the SIMS analyses confirm the TEM results, reveals that deposits of Cr could be detected in the vacuoles and xylem vessel elements of the roots of all plants, as well as in the cell walls of the stem parenchyma. Deposits in xylem cells were found by [6].

\section{References}

[1] M.A. Maine, M.V. Duarte, N.L.Suñé, Water Res. 35 (2001) 2629.

[2] M.N.V. Prasad, H.M.O. Freitas, Electron. J. Biotechnol. 6 (2003) 285.

[3] P.A.O. Mangabeira, L. Labejof, Alex-Alan F. Almeida, A.H. Oliveira, F. Escaig,. M.I.G. Severo, D.C. Silva, M. Salões, M.S. Mielke, E.R. Lucena, M.C. Martins, K.B. Santana, K.L. Gavrilov, P. Galle, R. Levi-Setti, Appl. Surf. Sci., 231 (2004) 497.

[4] P.A. Mangabeira, K.L. Gavrilov, A-A.F. Almeida, A.H. Oliveira, M.I. Severo, T.S Rosa, D.C, Silva, L. Labejof, F. Escaig, R, Levi-Setti, M.S, Mielke, Marie-Florence. G Loustalot, P. Galle, Appl. Surf. Sci. 252 (2006) 3488.

[5] A.K.Shanker, C. Cervantes, H. Loza-Tavera, S. Avudainayagam, Environ. Int. 31 (2005) 739.

[6] The authors wish to thanks Dr Ricardo Levi-Setti , Konstantin Gavrilov (Enrico Fermi Institute, University of Chicago) for their kind assistance with ICP-MS and ion microscopy imaging. This research was supported by CNPq (Conselho Nacional de Desenvolvimento Científico e Tecnológico, Brazil). 


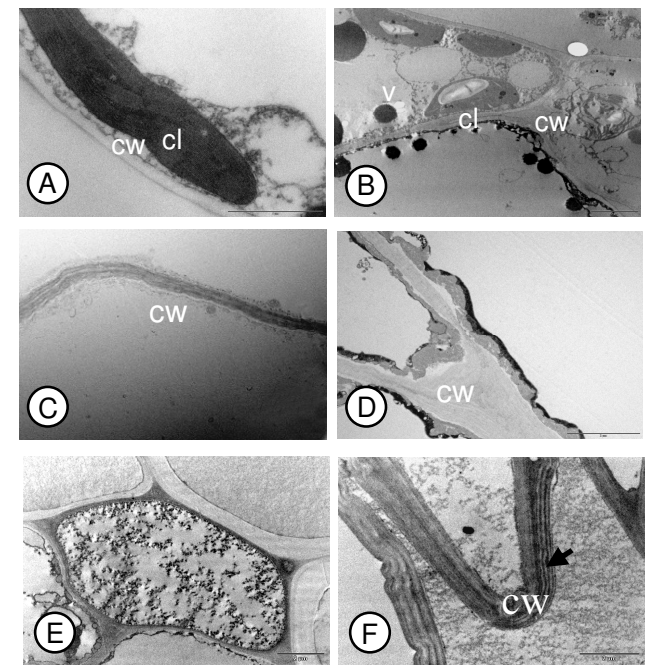

FIG 1. TEM electron micrographs of transversal sections of leaf, stem and root tissue of Polygonum ferrugineum following treatment of plants with $50 \mathrm{mg} \mathrm{L}^{-1} \mathrm{Cr}^{+3}$ : A) normal cell wall and normal chloroplast (cl) in a control leaf - Bar $=1 \mu \mathrm{m}$; B) electron dense material (arrowed) in cell wall (cw) and vacuole (v) of leaf - Bar $=2 \mu \mathrm{m} ; \mathrm{C}$ ) normal cell walls in a control stem - Bar $=2 \mu \mathrm{m} ; \mathrm{D}) \mathrm{Cr}^{+3}$ deposits (arrowed) in cell wall (cw) of stem - Bar $=2$ $\mu \mathrm{m}$; E) $\mathrm{Cr}^{+3}$ deposits (arrowed) in vacuole of root cell $\left.-\mathrm{Bar}=2 \mu \mathrm{m} ; \mathrm{F}\right) \mathrm{Cr}^{+3}$ deposits in cell wall (arrowed) of root cell - Bar $=2 \mu \mathrm{m}$
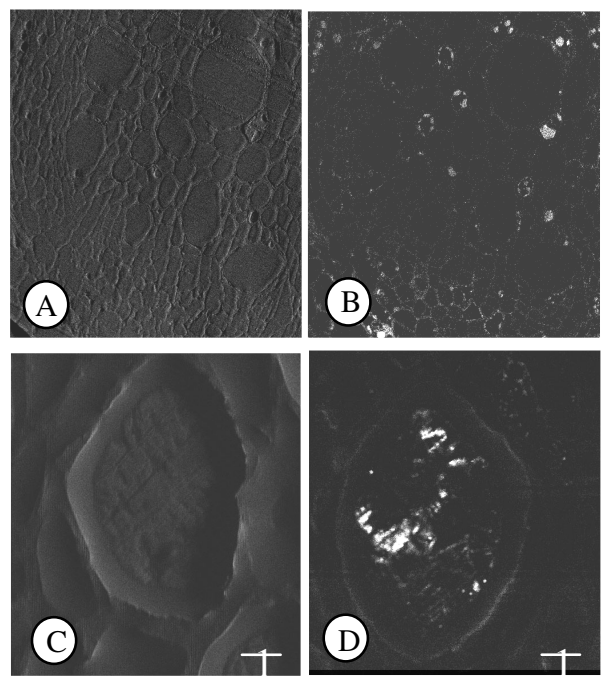

FIG 2. SIMS images of stem and root tissue of Polygonum ferrugineum following treatment of plants with $50 \mathrm{mg} \mathrm{L}^{-1} \mathrm{Cr}^{+3}$ : A) global topography of stem parenchyma; B) $\mathrm{Cr}^{+3}$ deposits in cell wall (cw) and vacuole (v) of stem parenchyma at a depth of $20 \mathrm{~nm}$; C) global topography of vessel element (ve) of root xylem; D) $\mathrm{Cr}^{+3}$ deposits in the vessel element (ve) of root xylem at a depth of $20 \mathrm{~nm}$. 